УДК 378.147.

DOI:10.15330/esu.14.121-126

\section{Вікторія Синишина,}

кандидат психологічних наук, доцент,

Державний вищий навчальний заклад

"Ужгородський національний університет"

(м. Ужгород, Україна)

Viktoriia Synyshyna,

Candidate of psychological sciences $(\mathrm{PhD})$,

Associate Professor, State University "Uzhhorod

National University" (Uzhhorod, Ukraine)

vsinishina@ukr.net

\title{
МІСЦЕ ІННОВАЦІЙНИХ ОСВІТНІХ ТЕХНОЛОГІЙ НА ПРАКТИЧНИХ ЗАНЯТТЯХ СТУДЕНТІВ ПСИХОЛОГІВ
}

\section{INNOVATIVE EDUCATIONAL TECHNOLOGIES IN PRACTICAL TRAINING OF STUDENTS PSYCHOLOGISTS}

У статті здійснено спробу визначити необхідість застосувания інновачійних технологій у дидактичі вищої иколи. Метою наиої статті $\epsilon$ науковий аналіз особливостей інновачійних методів проведения практичних занять зі студентами психологами, а саме, можливостей використання методу саse-study.

Проаналізовано та обтрунтовано ефективність такого методу проведення практичних занять зі студентами-психологами як саse-study, що мас у собі прогресивне начало, оскільки надає змогу під час творчого розгляду ситуачій ефективно виріиувати завдания майбутнього професіогенезу студентів-психологів. Кейс-метод формус навички у майбутніх психологів аналізувати практичні проблеми психологї̈, виробляти вміння формулювати запити ицодо конкретної психологічної ситуачіӥ.

Ключові слова:освітні технології, саse-study, кейс-метод,неігровий інтерактивний метод,освітня інновація.

It is obvious, that the learning process should ideally simulate the process of finding new knowledge. A method of studying when a student is placed in a situation where he himself masters problem solving in the process of studying, to a greater or lesser extent organized by a teacher, is common in foreign pedagogics. This is especially true for psychology students who have to provide psychological assistance in various problem situations in the process of future professional orientation, where the algorithm for solving a particular problem does not always work and there is a need for a creative vision of a solution for the client's problem.

This article attempts to determine the necessity of applying innovative technologies in high school didactics. The purpose of our article is a scientific analysis of the peculiarities of innovative methods of carrying out practical classes for psychology students, namely, the possibilities of using the method of case-study.

The effectiveness of this method of conducting practical classes with psychology students was analyzed as a case-study, which is progressive since it provides an opportunity to solve problems while forming a profession by psychology students effectively during the creative consideration of situations. Case-study method builds the skills of future psychologists to analyze practical problems of psychology, to develop the ability to make queries for a particular psychological situation.

With this method, students have an opportunity to show and improve their analytical and assessment skills, learn to work in a team, find the most rational solution for a problem. As an interactive learning method, the case-study method gains a positive attitude from students, providing theoretical knowledge and helping to master the practical use of the material; it affects the professionalization of students, promotes their maturing, generates interest and positive motivation in relation to learning. 
Key words: educational methods, case-study, case-study method, non-game interactive method, educational innovation.

Постановка проблеми. Найважливіше завдання вищої освіти - навчити молодих людей бути готовими до нових, динамічних умов професійної діяльності, розвинути вміння самостійно діяти в новому швидкоплинному інформаційному середовищі та ефективно використовувати його. Сучасна вища освіта повинна забезпечувати формування випускників, які здатні адаптуватися до умов професійної діяльності, що постійно змінюються. Проектування нових моделей освітнього процесу - основний напрям інноваційних перетворень у дидактиці вищої школи. Сьогодні стало очевидним, що викладачі мають можливість створювати і втілювати власні інноваційні методики. Навчальний процес в ідеалі повинен моделювати процес пошуку нових знань. Поширеним в зарубіжній педагогіці є таке навчання, в якому студент ставиться в ситуацію, коли він сам опановує вирішення проблем в процесі пізнання, в більшій чи меншій мірі організованого викладачем. У найбільш повному, розгорнутому вигляді таке навчання передбачає, що студент пропонує можливі рішення поставленої проблеми, перевіряє ці можливі рішення, порівнюючи його $з$ рішенням інших студентів, робить узагальнення. Особливо це $\epsilon$ актуальним для студентів-психологів, які покликані у процесі майбутнього професіогенезу надавати психологічну допомогу у різних проблемних ситуаціях, де не завжди спрацьовує алгоритм вирішення тієї чи іншої проблеми, а $є$ необхідність творчого бачення виходу із проблемної ситуації клієнта.

3 огляду на вищевказане, вкрай актуальним $\epsilon$ вивчення, аналіз та творче застосування як зарубіжного, так і вітчизняного досвіду використання інноваційного процесу у освітньому просторі вищої школи.

Аналіз останніх досліджень. Серед учених, які вели дослідження використання інноваційних технологій у навчальному процесі вищої школи, можна виокремити науковців: В. Байденко, В. Биков, О. Бугайов, І. Зимняя, М. Козяр, В. Кремень, А. Кузьмінський, О. Ляшенко, М. Майлз О. Прикота, А. Тряпицина, М. Фуллан, М. Хуберман. Вчені намагаються співвіднести поняття інновацій у педагогіці з такими характеристиками, як корисне, прогресивне, позитивне, сучасне, передове. Ми вважаємо, що внесок науковців у проблематику інноватики дуже значний, але потребують глибокого підходу ще поки що фрагментарні дослідження методу case-study, що має у собі прогресивне начало, що надає змогу під час творчого розгляду ситуацій ефективно вирішувати завдання майбутнього професіогенезу студентів-психологів.

Метою нашої статті є науковий аналіз особливостей інноваційних методів проведення практичних занять зі студентами - психологами, а саме, можливостей використання методу case-study.

Виклад основного матеріалу. Запровадження сучасних освітніх технологій на сучасному етапі розвитку українського суспільства $\epsilon$ нагальним не тільки в економіці, на підприємствах, а й у освітньому просторі. Під освітньою технологією ми розуміємо сукупність засобів, форм і методів навчання, спрямованих на формування необхідних знань, умінь, навичок, представлених за відповідною спеціальністю. Новостворені і вдосконалені конкурентоздатні технології - це перш за все інновації в галузі методики навчання i виховання, викладання i навчання, організації навчально-виховного процесу. Вони найбільш поширений і характерний тип нововведень у сфері освіти, що охоплює процес викладання природничо- 
наукових і гуманітарних дисциплін у сфері вищої освіти. Проблеми інноваційних технологій i методів у сучасній вищій освіті актуальні, оскільки посилилася тенденція до гуманізації і гуманітаризації змісту освіти. Безсумнівною перевагою інноваційних освітніх технологій $\epsilon$ не тільки отримання знань і формування практичних навичок, але й розвиток системи цінностей студентів, ідеалів, професійних позищій, життєвих установок, своєрідного професійного світовідчуття. У процесі засвоєння знань шляхом інноваційних освітніх технологій долається класичний недолік традиційного навчання, пов'язаний 3 неемоційністю викладу матеріалу, додаються емоції та народжується творча конкуренція.

На сучасному етапі розвитку педагогічної науки дослідники виділяють, теоретично обгрунтовують i впроваджують у навчальну діяльність такі новітні технології, як кейс-метод, метод проектної діяльності, креативну систему навчання, технологію розвитку цілісного мислення, технологію розвитку критичного мислення, технологію дистанційного навчання, ігрові технології, що сприяють моделюванню й імітації майбутньої професійної діяльності.

У процесі навчання традиційні методи проведення практичних занять важливо ініціювати новітніми інформаційними технологіями, оскільки такі технології забезпечують студентів та викладачів новими засобами та ресурсами комунікації, новими джерелами інформації. Успішно використовуючи традиційні джерела навчання такі, як наукова література, періодичні видання, студенти і викладачі наразі використовують нові on-line джерела інформації, які з'явилися завдяки бурхливому розвитку комунікацій. Це не може не впливати і на підходи до проведення занять. Одним 3 найбільш ефективних, дієвих методів навчання $\epsilon$ case study - це метод навчання на основі аналізу реальної ситуації; метод, що містить у собі спеціалізований навчальний матеріал, що включає кейс (текстовий опис подій), інструкцію чи питання до проблемної ситуації. Кейс-метод дає змогу наблизити навчання до реалій практичного життя. Саме для студентів психологів цей підхід $€$ нагальноважливим, оскільки вивчення предметів практичного та прикладного спрямування зумовлює необхідність розвитку таких вмінь, як вміння ефективно встановлювати контакт 3 клієнтами, ставити правильні питання і цим самим знаходити разом з клієнтами найоптимальніші альтернативні виходи із проблемних життєвих психологічних ситуацій. Відповідно ситуацій однакових не існує і тому важливо розробляти навички індивідуальних підходів до кожного клієнта.

Очевидно, що проблема впровадження методу case-study в практику вищої професійної освіти в даний час с актуальною, що зумовлено двома тенденціями:

- перша випливає із загальної спрямованості розвитку освіти, іiі орієнтації не стільки на отримання конкретних знань, скільки на формування професійної компетентності, умінь і навичок розумової діяльності, розвиток здібностей особистості, серед яких особлива увага приділяється здатності до навчання, зміну парадигми мислення, умінню переробляти величезні масиви інформації;

- друга випливає з розвитку вимог до якості фахівця, який, окрім задоволення вимог першої тенденції, повинен володіти також здатністю оптимальної поведінки в різних ситуаціях, відрізнятися системністю та ефективністю дій в умовах кризи [1, с. 95].

Метод case-study або метод конкретних ситуацій (від англійського case випадок, ситуація) - метод активного аналізу проблемних ситуацій, в основі якого лежить навчання шляхом вирішення конкретних завдань - ситуацій (вирішення кейсів). Він належить до неігрових імітаційних активних методів навчання. 
Мета методу case-study - проаналізувати ситуацію - case спільними зусиллями групи студентів психологів, i виробити практичне рішення; закінчення процесу оцінка запропонованих алгоритмів і вибір найкращого з них у контексті поставленої проблеми.

У розробці та впровадженні кейс-методу в практику підготовки менеджерів велику роль зіграла Гарвардська школа бізнесу в 1870 році, після цього метод casestudy почав використовуватись у підгоьовці економістів у зарубіжних країнах. Наразі активно розвиваються дві школи case-study - Гарвардська (американська) i Манчестерська (європейська). В рамках першої школи метою методу є навчання пошуку єдино вірного рішення, друга - передбачає багатоваріантність вирішення проблеми. Американські кейси зазвичай більші за обсягом (20 сторінок тексту), європейські міні-кейси менші за об'ємом. Лідером по збору і поширенню кейсів $\epsilon$ створений у 1973 році за ініціативою 22 вищих навчальних закладів Тhe Case Clearing House of Great Britain and Ireland; 31991 року він називається European Case Clearing House $(\mathrm{ECCH})$. В даний час до складу ЕCCH входить близько 340 організацій, серед яких The Harvard Business School Publishing, Інститут розвитку менеджменту (IMB) в Лозанні, в Швейцарії, INSEAD, у Фонтенбло у Франції, IESE в Барселоні в Іспанії, Лондонська бізнес-школа в Англії. У кожної з цих організацій своя колекція кейсів, право на розповсюдження яких має ECCH. Метод case-study насьогодні має одні з перших позицій в освіті, в зарубіжній практиці викладання дисциплін вважається одним 3 найефективніших способів навчання студентів навичкам вирішення типових проблем. Так Гарвардська школа бізнесу виділяє майже 90\% навчального часу на розбір конкретних кейсів, зберігаючи пріоритетне значення методу case-study в навчанні. Ситуаційне навчання за гарвардської методикою - це інтенсивний тренінг слухачів 3 використанням відеоматеріалів, комп'ютерного та програмного забезпечення. Середньостатистичний студент Гарварду або будь-який інший бізнес-школи за час свого навчання "опрацьовує" сотні кейсів. Щороку в Гарварді видаються сотні нових кейсів, методичних посібників і доповнень до колекції кейсів. Ставку на використання ситуаційного навчання також робить один 3 відомих університетів Північної Америки Університет Західного Онтаріо (Канада).

Метод case-study не потребує великих матеріальних та часових витрат й допускає варіантність навчання. Тим більше, як вказувалось вище, існують мінікейси або ситуаційні вправи, які не потребують 3 точки зору їх опрацювання великих часових витрат. А саме: проблемна ситуація може бути висвітлена на початку вивчення теми, іiі можна використовувати як основу у викладанні теоретичного матеріалу; проблемна ситуація може використовуватися 3 метою узагальнення та систематизації матеріалу. В такому разі іiі доцільно використовувати на практичних заняттях після попереднього опрацювання основного теоретичного матеріалу.

Завдання кейс-методу при проведенні практичних занять зі студентами психологами полягають у: - формуванні навичок аналізу практичних проблем психології на основі використання теоретичного матеріалу; - розвитку навичок аналізувати та оцінювати конкретну ситуацію, вести пошук теоретичної інформації, на основі якої вирішується практична ситуація; - виробленні вмінь формулювати запити щодо конкретної психологічної ситуації; - виробленні умінь розробляти підходи до реалізації плану дії; - формуванні вмінь розробляти гіпотези ситуаційних проблем; - формуванні навичок відстоювання власної позиції та чіткого 
висловлювання у диспуті та у виступі перед аудиторією; - формуванні вмінь та навичок конструктивної критики.

Як вже відзначалося, особливостями методу case-study є створення проблемної ситуації на основі фактів з реального життя, а також:

1. Метод призначений для отримання знань 3 дисциплін, істина в яких плюралістична, тобто немає однозначної відповіді на поставлене питання, а $є$ кілька відповідей, які можуть змагатися за ступенем істинності; завдання викладання при цьому відразу відхиляється від класичної схеми та орієнтована на отримання не єдиною, а багатьох істин і орієнтацію в їх проблемному полі.

2. Акцент навчання переноситься не на оволодіння готовим знанням, а на його вироблення, на співтворчість студента і викладача; звідси принципова відмінність методу case-study від традиційних методик - демократія в процесі отримання знання, коли студент по суті справи рівноправний з іншими студентами і викладачем в процесі обговорення проблеми.

3. Результатом застосування методу є не тільки знання, але й навички професійної діяльності.

4. Безсумнівною перевагою методу ситуаційного аналізу є не тільки отримання знань і формування практичних навичок, але й розвиток системи цінностей студентів, професійних позицій, життєвих установок, своєрідного професійного світовідчуття.

5. У методі case-study долається класичний дефект традиційного навчання, пов'язаний 3 “сухістю", неемоційністю викладу матеріалу - емоцій, творчої конкуренції і навіть боротьби в цьому методі так багато, що добре організоване обговорення кейса нагадує театральну виставу [1, с. 97].

Метод case-study - інструмент, що дозволяє застосувати теоретичні знання до вирішення практичних завдань. Метод сприяє розвитку у студентів самостійного мислення, уміння вислуховувати і враховувати альтернативну точку зору, аргументовано висловити свою. За допомогою цього методу студенти психологи мають можливість проявити і удосконалити аналітичні та оціночні навички, навчитися працювати в команді, знаходити найбільш раціональне рішення поставленої проблеми. Будучи інтерактивним методом навчання, метод case-study завойовує позитивне ставлення 3 боку студентів, забезпечуючи освоєння теоретичних положень та оволодіння практичним використанням матеріалу; він впливає на професіоналізацію студентів, сприяє їх дорослішання, формує інтерес та позитивну мотивацію по відношенню до навчання.

Одночасно метод case-study $\epsilon$ i засобом розвитку творчого мислення викладача, і виступає як спосіб реалізації творчого підходу до педагогічних завдань, що дозволяє по-іншому думати і діяти, оновлювати свій творчий потенціал.

Передбачається, що в психологічній практиці не існує однозначно правильних piшень. Суть навчання методом case-study полягає в тому, що кожен пропонує варіанти, виходячи з наявних у нього знань, практичного досвіду та інтуїції.

Практичне заняття з використанням методу конкретних ситуацій підвишує ефективність засвоєння навчального матеріалу, що дає змогу зменшити час на вивчення навчальної дисципліни. Основними умовами ефективного навчання за допомогою кейс-стаді $€$ ретельна підготовка до занять в аудиторії, забезпечення високої якості обговорення й активної участі й взаємодії між студентами.

Отже, на практичних заняттях важливо навчити студентів психологів проводити вдумливу роботу над рішенням проблематичних завдань, вміти 
аргументовано висловлювати власні думки, розширювати професійну лексику та вміння відповідного освітньо-кваліфікаційного рівня.

Звертаючись до застосування описаного вище методу case-study, варто зауважити, що впровадження лише case study як безальтернативної форми навчання у процес проведення практичних занять 3 психологічних дисциплін не є методично правильним, тому необхідно застосовувати й інші методи та форми навчання в їхньому органічному поєднанні. Варто пам'ятати, що ефективність використання case study залежить від майстерного його поєднання 3 традиційними методами навчання. Було 6 методичною помилкою намагатися побудувати весь курс практичних занять з психологічних дисципліни лише на основі розгляду конкретних ситуацій. Мистецтво навчання в сучасних умовах передбачає використання різних методів та технологій, тому доцільно виділяти на вивчення конкретних ситуацій в середньому 25-30\% від часового розподілу практичного заняття.

Висновки. Таким чином, проаналізувавши необхідність застосування кейсметоду на практичних заняттях $з$ психологічних дисциплін для студентів-психологів, можемо прийти до висновку, що використанням методу конкретних ситуацій підвищує ефективність засвоєння навчального матеріалу. Подальших досліджень потребує конкретизація основних етапів роботи над кейсами 3 конкретно визначених дисциплін психологічного спрямування.

\title{
Література
}

1. Пащенко Т. Кейс-метод як сучасна технологія навчання спеціальних дисциплін / Т. Пащенко // Молодь і ринок. - 2015. - № 8. - С. 94-99.

References

1. Pashhenko T. Kejs-metod yak suchasna texnologiya navchannya special'ny'x dy'scy'plin / T. Pashhenko // Molod’ i ry’nok. - 2015. - \# 8. - S. 94-99.

Одержано статтю: 4.10 .2018

Прийнято до друку: 18.10.2018

УДК :373.2.011.3-51

DOI:10.15330/esu.14.126-134

\author{
Тетяна Танько, \\ доктор педагогічних наук, професор, \\ Харківський національний педагогічний \\ університет імені Г.С.Сковороди \\ (м. Харків, Україна) \\ Tetiana Tanko, \\ Doctor of pedagogical sciences, Professor, \\ H.S. Skovoroda Kharkiv National Pedagogical \\ University (Kharkiv, Ukraine) \\ faculty-pre-school@hnpu.edu.ua
}

\section{ТЕОРЕТИЧНІ АСПЕКТИ ФОРМУВАННЯ ПРОФЕСІЙНО-ЗНАЧУЩИХ ЯКОСТЕЙ ОСОБИСТОСТІ ВЧИТЕЛЯ, ВИХОВАТЕЛЯ ЗАКЛАДУ ДОШКІЛЬНОЇ ОСВІТИ}

\author{
THEORETICAL ASPECTS OF FORMING PROFESSIONALLY IMPORTANT \\ QUALITIES OF THE PERSONALITY OF TEACHER AS AN EDUCATOR OF \\ PRESCHOOL EDUCATIONAL INSTITUTION
}

У статті висвітлено значущість професійно-значуиих якостей особистості вчителя, вихователя закладу дошкільної освіти, розкрито погляди вітчизняних педагогів минулого та сучасності на особливості їх формування. Наголочено, що якості особистості педагога є творчим компонентом педагогічної майстерності, яка містить у собі мобільність і орихінальність мислення; вміння враховувати мінливість прочесу 